\title{
Em busca de uma teoria que explique o conceito aplicado
}

\author{
Luís Marques*, Cristiano Morini
}

\section{Resumo}

Os benefícios da aplicabilidade do programa de operador econômico autorizado (OEA) são suportados por teorias relacionadas à cadeia de suprimentos. Neste trabalho foram identificadas as teorias que mais se relacionam com este tema e assim foi possível identificar vantagens competitivas que o programa fornece. Em um primeiro momento foram exploradas teorias relacionadas e, em seguida, foi apresentado dados sobre o programa de OEA no mundo e foi utilizado o programa brasileiro como exemplo. Dentre os resultados, identificou-se a teoria das agências e teoria dos custos transacionais como as que mais contribuiram com o objetivo do trabalho. Nada melhor que uma teoria na prática.

\section{Palavras-chave: Teoria, Operador econômico autorizado, Compliance.}

\section{Introdução}

Com o intuito de dinamizar os fluxos comercias das aduanas, tornando-as mais ágeis, sem perder a rigidez nos controles das mercadorias, vários países adotaram um programa de operador econômico autorizado com base nas recomendações da Organização Mundial das Aduanas (OMA) (RFB, 2019).

Trata-se de um programa de cumprimento voluntário dos critérios de segurança sobrepostos à cadeia de suprimentos e obrigações tanto tributárias quanto aduaneiras (GARCÍA, 2008). Os resultados desta adoção vêm sinalizando grandes ganhos qualitativos $e$ quantitativos para todos os envolvidos no comércio internacional. A sua criação no Brasil e no mundo é considerada recente e por isso faz-se necessário identificar referenciais teóricos que suportem os benefícios da aplicabilidade do programa OEA.

\section{Resultados e Discussão}

As análises de dados deram suporte à revisão bibliográfica deste trabalho e assim foram exploradas várias teorias.

É possível identificar na tabela 1 as principais teorias exploradas nesta pesquisa. $\mathrm{Na}$ coluna definição encontra-se um pequeno resumo que sustentou as relações feitas.

Tabela 1. Teorias relacionadas à administração da cadeia de suprimentos

\begin{tabular}{c|c|c}
\hline Teoria & Definição & Referências \\
\hline $\begin{array}{c}\text { Teoria dos } \\
\text { custos de } \\
\text { transação }\end{array}$ & $\begin{array}{c}\text { Os principais determinantes da } \\
\text { forma de organização das } \\
\text { empresas são as transações e os } \\
\text { custos ao se recorrer ao mercado. }\end{array}$ & $\begin{array}{c}\text { Hitt (2011); } \\
\text { Williamson } \\
(2008) ;\end{array}$ \\
\hline $\begin{array}{c}\text { Teoria das } \\
\text { agências }\end{array}$ & $\begin{array}{c}\text { Atividades que envolvem } \\
\text { interesse próprio, aversão ao } \\
\text { risco, conflito de objetivos e falta } \\
\text { de confiança. }\end{array}$ & $\begin{array}{c}\text { Fayezi, } \\
\text { O'Loughlin e } \\
\text { Zutchi (2012) }\end{array}$ \\
\hline $\begin{array}{c}\text { Teoria } \\
\text { institucional }\end{array}$ & $\begin{array}{c}\text { Tomadas de decisões } \\
\text { influenciadas fortemente por } \\
\text { normas externas, valores e } \\
\text { tradições. }\end{array}$ & $\begin{array}{c}\text { Tate, Dooley e } \\
\text { Ellram (2011) }\end{array}$ \\
\hline $\begin{array}{c}\text { Teoria da troca } \\
\text { social }\end{array}$ & $\begin{array}{c}\text { Benefícios conjuntos obtidos por } \\
\text { meio de trocas entre parceiros } \\
\text { comerciais. }\end{array}$ & $\begin{array}{c}\text { Hitt (2011); Wu, } \\
\text { Chuang e Hsu } \\
(2014)\end{array}$ \\
\hline $\begin{array}{c}\text { Visão baseada } \\
\text { em recursos }\end{array}$ & $\begin{array}{c}\text { Papel dos gerentes na agregação, } \\
\text { estruturação e alavancagem dos } \\
\text { recursos da empresa. }\end{array}$ & $\begin{array}{c}\text { Hitt (2011); } \\
\text { Carter e Rogers } \\
(2008)\end{array}$ \\
\hline
\end{tabular}

As Mercadorias paradas na aduada causam mais custos transacionais para uma empresa não certificada como operador econômico autorizado, pois as chances de se obter um canal vermelho são muito maiores. Com isso se perde mais dinheiro e não se agrega valor nenhum a mercadoria. O maior custo de transação identificado e que mais afeta as companhias não certificadas como OEA é o custo de armazenagem. Estes custos, junto a outros custos de transação podem trazer grandes desvios inesperados e perdas expressivas.

A teoria das agências direcionou as assimetrias informacionais existentes. O principal delega as funções para os agentes abrindo espaço para conflitos de interesse. Os OEAs estão menos propensos a conflitos de interesses entre os órgãos que atuam na liberação das mercadorias.

\section{Conclusões}

Com as teorias identificadas é possível afirmar que uma empresa certificada como OEA diminui gradativamente seus custos de transação. Tal fato ocorre, pois, a empresa ganha mais tempo e previsibilidade nos seus processos. Esta empresa também com seus processos mais seguros, previsíveis e rápidos está menos suscetível a conflitos de interesses e aversão ao risco, citados pela teoria das agências.

\section{Agradecimentos}

Agradeço ao apoio financeiro concedido pelo CNPq, a minha família, amigos e ao meu orientador Cristiano Morini, pela dedicação e disposição.

FAYEZI, S.; O’LOUGHLIN, A.; ZUTSHI, A. Agency theory and supply chain management: a structured literature review. Supply Chain Management: An International Journal, v. 17, n. 5, pp. 556-570. 2012.

HITT, M. Relevance of strategic management theory and research for supply chain management. Journal of Supply Chain Management, v. 47, n. 1, p. 9. 2011.

RFB. RECEITA FEDERAL DO BRASIL. Perguntas \& Respostas - Programa Brasileiro de OEA. 2019. Disponível em: <http://idg.receita.fazenda.gov.br/orientacao/aduaneira/importacao-eexportacao/oea/arquivos-e-imagens/arquivos/perguntas-respostas.pdf $>$. Acesso em: 12 dez. 2018.

TATE, W.; DOOLEY, K.; ELLRAM, L. Transaction Cost and Institutional Drivers of Supplier Adoption of Environmental Practices. Journal of Business Logistics, v.32, n.1, pp. 6-16. 2011.

WILLIAMSON, O. E. The Economics of Organisation: The Transaction Cost Approach. American Journal of Sociology, 87(3), 548-577. 1981. 